\title{
Syntheses, structural studies and solution properties of iron complexes of some amide-substituted calixarenes
}

\author{
Mark I. Ogden, ${ }^{* a}$ Brian W. Skelton $^{b}$ and Allan H. White ${ }^{b}$ \\ ${ }^{a}$ Department of Applied Chemistry, Curtin University of Technology, GPO Box U 1987, \\ Western Australia 6845, Australia \\ ${ }^{b}$ Department of Chemistry, University of Western Australia, Crawley, Western Australia 6009, \\ Australia.E-mail: mark@crystallization.curtin.edu.au
}

Received 5th June 2001, Accepted 16th August 2001

First published as an Advance Article on the web 27th September 2001

\begin{abstract}
Iron(III) complexes of 5,11,17,23-tetra-tert-butyl-24-hydroxy-26,27,28-tris(diethylcarbamoylmethoxy)calix[4]arene (II) and 5,11,17,23,29,35-hexa-tert-butyl-36,39-dihydroxy-37,38,40,41-tetrakis(diethylcarbamoylmethoxy)calix[6]arene (IV) have been synthesised, and a single crystal structure determination has been carried out on [Fe(II - H)]$\left(\mathrm{FeCl}_{4}\right)_{2}$; the iron in the complex cation is bound to all seven $\mathrm{O}$ atoms of the calixarene with the shortest $\mathrm{Fe}-\mathrm{O}$ distance to the phenolate $\mathrm{O}$ atom. The voltammetric properties of these complexes and the previously described $\mathrm{Fe}$ (III) complex of 5,11,17,23-tetra-tert-butyl-25,27-dihydroxy-26,28-bis(diethylcarbamoylmethoxy)calix[4]arene (I) have been studied. The results suggest that the complexes of I and II undergo a reduction which is metal-centred, and an oxidation which is ligand-centred.
\end{abstract}

\section{Introduction}

The calixarene macrocyclic framework continues to attract attention as a starting point for the development of cation receptors. ${ }^{1}$ Amongst the many approaches available for elaborating calixarenes, amide functionalisation through $\mathrm{O}$-alkylation has produced ionophores with high selectivities, ${ }^{2}$ particularly for alkali and alkaline earth metal cations, ${ }^{3}$ although complexation with the lanthanide cations, ${ }^{4,5}$ and to a lesser extent, d-block transition metal cations ${ }^{6-8}$ has also been studied.

In particular, structural studies of iron complexes of amidesubstituted calix[4]arenes have been reported, where the extent of substitution at the phenolic oxygen atoms influences the oxidation state of the iron species in the complex; thus an Fe(III) complex is isolated with the bis-substituted calix[4]arene (I) ${ }^{8}$ while an $\mathrm{Fe}(\mathrm{II})$ complex is obtained from reaction with the tetrasubstituted calix[4] arene (III). ${ }^{7}$ The aim of the present work was to study the electrochemical properties of such species, while systematically varying the structure of the calixarene ligand. Reported here are the syntheses of the calix[6]arene amides IV and $\mathbf{V}$ together with voltammetric and UV/vis spectroscopic studies of iron complexes of $\mathbf{I}, \mathbf{I I}$, and IV. The structure of the complex $[\mathrm{Fe}(\mathbf{I I}-\mathrm{H})]\left(\mathrm{FeCl}_{4}\right)_{2}$ is also described.

\section{Experimental}

\section{Syntheses}

5,11,17,23-Tetra-tert-butyl-25,27-dihydroxy-26,28-bis(diethylcarbamoylmethoxy)calix[4]arene (I) ${ }^{9} \quad 5,11,17,23$-tetra-tertbutyl-25,26,27,28-tetrakis(diethylcarbamoylmethoxy)calix[4]arene $(\mathbf{I I I}),{ }^{10}[\mathrm{Fe}(\mathrm{I}-2 \mathrm{H})]\left(\mathrm{ClO}_{4}\right)_{2}(\mathbf{1})^{8}$ and $[\mathrm{Fe}(\mathrm{III})]\left(\mathrm{ClO}_{4}\right)_{2}(\mathbf{3})^{7}$ were synthesised by literature methods.

CAUTION: Although no apparent hazards were encountered in this work, metal perchlorates are potentially explosive and should be prepared only in small amounts and handled with care.

\section{Ligand syntheses}

5,11,17,23-Tetra-tert-butyl-24-hydroxy-26,27,28-tris(diethylcarbamoylmethoxy)calix[4]arene (II). The literature procedure for tris-substitution ${ }^{11}$ of $p$-tert-butylcalix[4]arene was used as
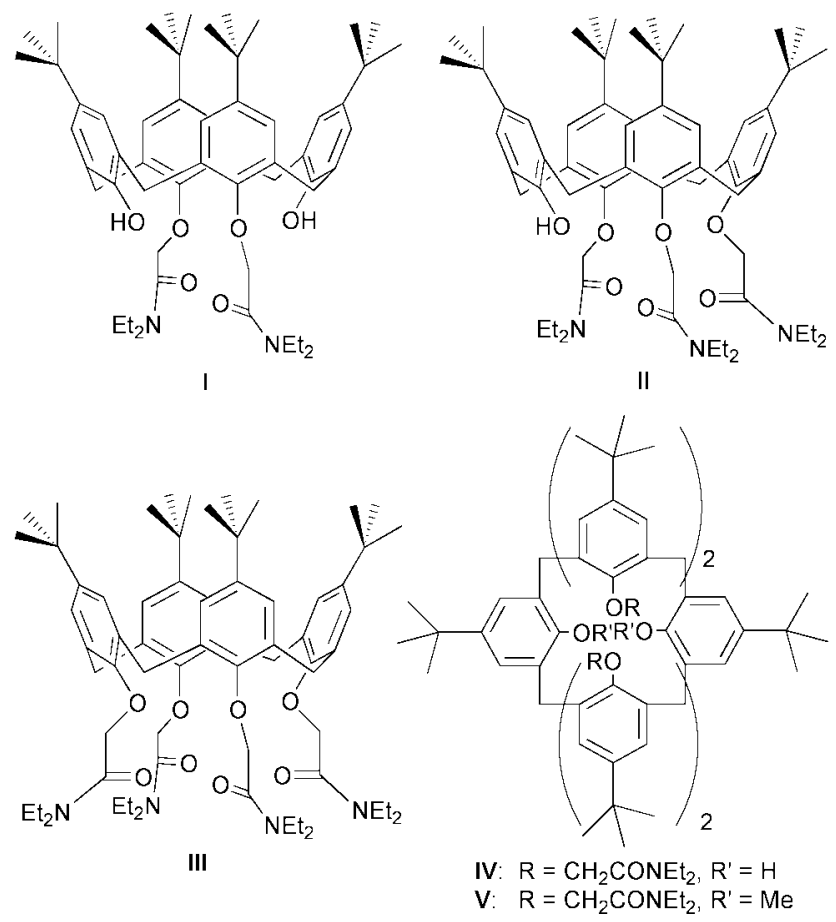

follows. p-tert-Butylcalix[4]arene-toluene $(1.14 \mathrm{~g}, 1.54 \mathrm{mmol})$ was added to a slurry of $\mathrm{BaO}(1.59 \mathrm{~g}, 2.36 \mathrm{mmol})$ and $\mathrm{Ba}(\mathrm{OH})_{2}$. $8 \mathrm{H}_{2} \mathrm{O}(1.70 \mathrm{~g}, 5.4 \mathrm{mmol})$ in $\mathrm{dmf}\left(30 \mathrm{~cm}^{3}\right)$ and stirred at room temperature for $1 \mathrm{~h}$, under an inert atmosphere. A solution of 2-chloro- $N, N$-diethylacetamide $(1.86 \mathrm{~g}, 15.4 \mathrm{mmol})$ in $\mathrm{dmf}$ $\left(10 \mathrm{~cm}^{3}\right)$ was then added dropwise, and the mixture stirred for $1 \mathrm{~h}$, after which $1 \mathrm{M} \mathrm{HCl}\left(100 \mathrm{~cm}^{3}\right)$ was added. The aqueous solution was extracted with dichloromethane $\left(3 \times 20 \mathrm{~cm}^{3}\right)$. The dichloromethane extracts were combined, washed with water (2 $\times 20 \mathrm{~cm}^{3}$ ) and dried over $\mathrm{MgSO}_{4}$. The solvent was removed to give a pale yellow solid which was purified by column chromatography on silica, eluting the product with dichloromethanetoluene-methanol $(8: 1: 1, \mathrm{v} / \mathrm{v})$. Recrystallisation from petrol $\left(b_{p} 60-80^{\circ} \mathrm{C}\right)$-toluene gave the product as a white microcrystalline solid $(0.35 \mathrm{~g}$, yield 23\%). (Found: C, 75.5; H, 9.11; N, 4.31 . 
$\mathrm{C}_{62} \mathrm{H}_{89} \mathrm{~N}_{3} \mathrm{O}_{7}$ requires $\mathrm{C}, 75.3 ; \mathrm{H}, 9.08 ; \mathrm{N}, 4.25 \%$ ). Mass spectrum (FAB): $m / z 988\left[\mathrm{M}^{+}\right], 1010\left[\mathrm{M}^{+}-\mathrm{H}+\mathrm{Na}\right]$. NMR $\left(\mathrm{CDCl}_{3}\right):{ }^{1} \mathrm{H}, \delta 0.95\left[\mathrm{~s}, 18 \mathrm{H}, \mathrm{C}\left(\mathrm{CH}_{3}\right)_{3}\right], 1.17\left[\mathrm{~s}, 9 \mathrm{H}, \mathrm{C}\left(\mathrm{CH}_{3}\right)_{3}\right]$, 1.19 [s, 9H, C( $\left.\left.\mathrm{CH}_{3}\right)_{3}\right], 1.11-1.27$ (br m, 18H, $\mathrm{NCH}_{2} \mathrm{CH}_{3}$ ), 3.19 (d, $\left.J=13 \mathrm{~Hz}, 2 \mathrm{H}, \mathrm{CH}_{2}\right), 3.24\left(\mathrm{~d}, J=13 \mathrm{~Hz}, 2 \mathrm{H}, \mathrm{CH}_{2}\right), 3.27-3.47$ (br m, 12H, $\left.\mathrm{NCH}_{2}\right), 4.51\left(\mathrm{~d}, J=13 \mathrm{~Hz}, 2 \mathrm{H}, \mathrm{CH}_{2}\right), 4.55(\mathrm{~d}, J=14$ $\left.\mathrm{Hz}, 2 \mathrm{H}, \mathrm{OCH}_{2}\right), 5.05\left(\mathrm{~d}, J=14 \mathrm{~Hz}, 2 \mathrm{H}, \mathrm{OCH}_{2}\right), 5.09$ (d, $J=13$ $\left.\mathrm{Hz}, 2 \mathrm{H}, \mathrm{CH}_{2}\right), 5.10\left(\mathrm{~s}, 2 \mathrm{H}, \mathrm{OCH}_{2}\right), 6.67(\mathrm{~d}, J=2.3 \mathrm{~Hz}, 2 \mathrm{H}$ $\mathrm{ArH}), 6.70(\mathrm{~d}, J=2.3 \mathrm{~Hz}, 2 \mathrm{H}, \mathrm{ArH}), 6.87(\mathrm{~s}, 2 \mathrm{H}, \mathrm{ArH}), 6.93$ (s, 2H, ArH), 7.86 (s, $1 \mathrm{H}, \mathrm{OH}) .{ }^{13} \mathrm{C}, \delta 13.02$ (br), 14.06, 14.25 $\left(\mathrm{CH}_{2} \mathrm{CH}_{3}\right), 31.14,31.46,31.60\left[\mathrm{C}\left(\mathrm{CH}_{3}\right)_{3}\right], 31.69,32.09\left(\mathrm{CH}_{2}\right)$, $33.61,33.73,33.87\left[\mathrm{C}_{\left.\left(\mathrm{CH}_{3}\right)_{3}\right],} 39.95,40.22,40.89,41.44\right.$ $\left(\mathrm{CH}_{2} \mathrm{CH}_{3}\right), 71.08,72.59\left(\mathrm{OCH}_{2}\right), 124.69,125.09,125.31,125.75$ (aromatic CH), 127.67, 132.99, 133.20, 134.23, 140.25, 145.05, 145.58, 150.47, 152.71, 153.66 (aromatic C), 168.14, 169.74 $(\mathrm{C}=\mathrm{O})$.

$5,11,17,23,29,35-H e x a-t e r t-b u t y l-36,39-d i h y d r o x y-37,38,40,-$ 41-tetrakis(diethylcarbamoylmethoxy)calix[6]arene (IV). A slurry of $p$-tert-butylcalix[6]arene $(2.0 \mathrm{~g}, 2.1 \mathrm{mmol})$ and $\mathrm{NaH}$ $(60 \%$ dispersion in oil, $1.1 \mathrm{~g}, \approx 27 \mathrm{mmol})$ in $\mathrm{dmf}\left(10 \mathrm{~cm}^{3}\right)$ and thf $\left(120 \mathrm{~cm}^{3}\right)$ was stirred at $\mathrm{rt}$ for $1 \mathrm{~h}$, under an inert atmosphere. Potassium iodide $(2.7 \mathrm{~g}, 16 \mathrm{mmol})$ and 2-chloro- $\mathrm{N}, \mathrm{N}$ diethylacetamide ( $2.46 \mathrm{~g}, 16 \mathrm{mmol})$ were then added, and the resulting mixture heated at reflux for $18 \mathrm{~h}$. The solvents were then removed at reduced pressure, and $1 \mathrm{M} \mathrm{HCl}\left(100 \mathrm{~cm}^{3}\right)$ was added to the residue. The resulting off-white solid was collected by filtration, washed with water $\left(3 \times 50 \mathrm{~cm}^{3}\right)$, and dissolved in dichloromethane $\left(50 \mathrm{~cm}^{3}\right.$ ). Hexane (approx. $50 \mathrm{~cm}^{3}$ ) was added until a brown oil separated. The mother liquor was decanted from the oil, and upon further evaporation, white crystals of the product were precipitated. Recrystallisation from dichloromethane-acetonitrile gave the product as a white microcrystalline solid $(0.8 \mathrm{~g}$, yield $27 \%$ ). (Found: C, 75.6; $\mathrm{H}$ 8.74; $\mathrm{N}, 4.09 . \mathrm{C}_{90} \mathrm{H}_{128} \mathrm{~N}_{4} \mathrm{O}_{10}$ requires $\mathrm{C}, 75.8 ; \mathrm{H}, 9.05 ; \mathrm{N}, 3.93 \%$ ). Mass spectrum (FAB): $\mathrm{m} / \mathrm{z} 1426\left[\mathrm{M}^{+}\right]$.

$5,11,17,23,29,35$-Hexa-tert-butyl-36,39-dimethoxy-37,38,40,41-tetrakis(diethylcarbamoylmethoxy)calix[6]arene (V). A slurry of IV $(0.10 \mathrm{~g}, 0.070 \mathrm{mmol})$ and $\mathrm{K}_{2} \mathrm{CO}_{3}(0.10 \mathrm{~g}, 0.72$ $\mathrm{mmol})$ in acetonitrile $\left(50 \mathrm{~cm}^{3}\right)$ was heated at reflux for $1 \mathrm{~h}$ under an inert atmosphere. Methyl iodide $(0.10 \mathrm{~g}, 0.69 \mathrm{mmol})$ was added, and the mixture heated at reflux for $12 \mathrm{~h}$. The mixture was then filtered and the solvent removed at reduced pressure The yellow residue was dissolved in dichloromethane $\left(30 \mathrm{~cm}^{3}\right)$, and the solution was washed with water $\left(3 \times 20 \mathrm{~cm}^{3}\right)$. The organic layer was dried $\left(\mathrm{MgSO}_{4}\right)$, filtered, and ethanol added $\left(20 \mathrm{~cm}^{3}\right)$. Upon evaporation the product was precipitated as off-white crystals $(0.06 \mathrm{~g}$, yield $60 \%$ ). (Found: C, 76.0; H, 9.18; $\mathrm{N}, 3.84 . \mathrm{C}_{92} \mathrm{H}_{132} \mathrm{~N}_{4} \mathrm{O}_{10}$ requires $\mathrm{C}, 76.0 ; \mathrm{H}, 9.15 ; \mathrm{N}, 3.85 \%$ ). Mass spectrum (FAB): $m / z 1454\left[\mathrm{M}^{+}\right]$. NMR $\left(\mathrm{CDCl}_{3}\right):{ }^{1} \mathrm{H}$, $\delta 1.05\left[\mathrm{~s}, 36 \mathrm{H}, \mathrm{C}\left(\mathrm{CH}_{3}\right)_{3}\right], 1.37\left[\mathrm{~s}, 18 \mathrm{H}, \mathrm{C}\left(\mathrm{CH}_{3}\right)_{3}\right], 1.15-1.25 \mathrm{br}$ $\left.\mathrm{m}, 24 \mathrm{H}, \mathrm{NCH}_{2} \mathrm{CH}_{3}\right), 1.46\left(\mathrm{~s}, 6 \mathrm{H}, \mathrm{OCH}_{3}\right), 3.38(\mathrm{~d}, J=15 \mathrm{~Hz}$ $4 \mathrm{H}, \mathrm{CH}_{2}$ ), 3.45-3.65 (br m, 16H, $\left.\mathrm{NCH}_{2}\right), 3.99$ (s, 4H, $\mathrm{CH}_{2}$ ), $4.35\left(\mathrm{~d}, J=15 \mathrm{~Hz}, 4 \mathrm{H}, \mathrm{CH}_{2}\right), 4.40\left(\mathrm{~d}, J=12 \mathrm{~Hz}, 4 \mathrm{H}, \mathrm{OCH}_{2}\right)$, $4.69\left(\mathrm{~d}, J=12 \mathrm{~Hz}, 4 \mathrm{H}, \mathrm{OCH}_{2}\right), 6.55(\mathrm{~d}, J=2.1 \mathrm{~Hz}, 4 \mathrm{H}, \mathrm{ArH})$, $7.21(\mathrm{~s}, 4 \mathrm{H}, \mathrm{ArH}), 7.61(\mathrm{~d}, J=2.1 \mathrm{~Hz}, 4 \mathrm{H}, \mathrm{ArH}) .{ }^{13} \mathrm{C}, \delta 12.87$, $14.54\left(\mathrm{CH}_{2} \mathrm{CH}_{3}\right), 31.29,31.56\left[\mathrm{C}\left(\mathrm{CH}_{3}\right)_{3}\right], 29.92,32.36\left(\mathrm{CH}_{2}\right)$, 34.16, 34.21 [C( $\left.\left(\mathrm{CH}_{3}\right)_{3}\right], 40.11,41.79\left(\mathrm{CH}_{2} \mathrm{CH}_{3}\right), 58.80\left(\mathrm{OCH}_{3}\right)$, $72.18\left(\mathrm{OCH}_{2}\right), 123.30,127.28,127.88$ (aromatic $\left.\mathrm{CH}\right), 132.48$, $132.72,134.16,145.79,146.47,152.30,154.80$ (aromatic C), $167.29(\mathrm{C}=\mathrm{O})$

\section{Complex syntheses}

Complex 2a, [ Fe(II - H)](ClO $)_{2}$. The calixarene II $(0.15 \mathrm{~g}$, $0.15 \mathrm{mmol}$ ) was dissolved in $1: 1$ dichloromethane-ethanol $(2 \mathrm{ml})$. An approximately three fold excess of $\mathrm{Fe}\left(\mathrm{ClO}_{4}\right)_{2} \cdot 6 \mathrm{H}_{2} \mathrm{O}$ was added, resulting in a deep green solution which was filtered. Upon slow evaporation the product precipitated as small dark green crystals. (Yield: 80\%). (Found: C, 60.1; H, 7.21; N, 3.21. $\mathrm{C}_{62} \mathrm{H}_{88} \mathrm{Cl}_{2} \mathrm{FeN}_{3} \mathrm{O}_{15}$ requires $\mathrm{C}, 60.0 ; \mathrm{H}, 7.14 ; \mathrm{N}, 3.38 \%$ ). Mass spectrum (FAB): $m / z 1043\left[\left\{\mathrm{M}-2\left(\mathrm{ClO}_{4}\right)\right\}\right], 1142[\{\mathrm{M}-$ $\left.\left.\left(\mathrm{ClO}_{4}\right)\right\}^{+}\right]$.

Complex 2b, [ Fe(II - H)]( $\left.\mathrm{FeCl}_{4}\right)_{2}$. The calixarene II $(0.15 \mathrm{~g}$, $0.15 \mathrm{mmol}$ ) was dissolved in $1: 1$ dichloromethane-ethanol $(2 \mathrm{ml})$. An approximately three fold excess of $\mathrm{FeCl}_{3}$ was added, resulting in a deep green solution which was filtered. Upon slow evaporation the product precipitated as dark green rhombic crystals suitable for X-ray diffraction studies. (Yield: 70\%). (Found: C, 51.6; $\mathrm{H}, 6.12 ; \mathrm{N}, 3.20 . \mathrm{C}_{62} \mathrm{H}_{88} \mathrm{Cl}_{8} \mathrm{Fe}_{3} \mathrm{~N}_{3} \mathrm{O}_{7}$ requires C, 51.8; H, 6.17; N, 2.92\%). Mass spectrum (FAB): $\mathrm{m} / \mathrm{z} 1043$ $\left[\left\{\mathrm{M}-2\left(\mathrm{FeCl}_{4}\right)\right\}^{+}\right]$.

Complex 4, [ Fe(IV - H)] $\left(\mathrm{ClO}_{4}\right)_{2}$. The calixarene IV $(0.14 \mathrm{~g}$, $0.10 \mathrm{~mol}$ ) was dissolved in $1: 1$ dichloromethane-ethanol $(2 \mathrm{ml})$. An approximately three fold excess of $\mathrm{Fe}\left(\mathrm{ClO}_{4}\right)_{2} \cdot 6 \mathrm{H}_{2} \mathrm{O}$ was added, resulting in a deep green solution which was filtered. Upon slow evaporation the product precipitated as small dark green crystals, often contaminated with a red amorphous precipitate. (Yield: 40-50\%). (Found: C, 61.6; H, 8.07; N, 3.01. $\mathrm{C}_{90} \mathrm{H}_{127} \mathrm{Cl}_{2} \mathrm{FeN}_{4} \mathrm{O}_{18} \cdot 4 \mathrm{H}_{2} \mathrm{O}$ requires $\mathrm{C}, 61.7 ; \mathrm{H}, 7.77 ; \mathrm{N}, 3.20 \%$ ). Mass spectrum (FAB): $m / z 1480\left[\left\{\mathrm{M}-2\left(\mathrm{ClO}_{4}\right)-\mathrm{H}\right\}^{+}\right]$.

\section{Electrochemistry}

Following published procedures ${ }^{12 a}$ measurements were made using a MacLab Potentiostat, controlled by the Echem software package, ${ }^{12 b}$ via a MacLab/2e. All reported voltammograms were recorded on the first sweep. Electrochemical solutions were prepared at $1.0 \times 10^{-3} \mathrm{~mol} \mathrm{dm}^{-3}$ in freshly distilled solvent. $\mathrm{Bu}_{4} \mathrm{NBF}_{4}$ was then added as supporting electrolyte $\left(0.10 \mathrm{~mol} \mathrm{dm}^{-3}\right)$. The electrochemical cell was an unsealed, onecompartment cell with a glassy carbon disc working electrode, an $\mathrm{Ag} / \mathrm{Ag}^{+}$reference electrode $\left(1.0 \times 10^{-3} \mathrm{~mol} \mathrm{dm}{ }^{-3} \mathrm{AgNO}_{3}\right.$, $0.10 \mathrm{~mol} \mathrm{dm}^{-3} \mathrm{Bu}_{4} \mathrm{NBF}_{4}$ in $\mathrm{CH}_{3} \mathrm{CN}$ ) and a platinum-wire counter electrode. Argon, saturated with the appropriate solvent, was used at all times for solution degassing. Ferrocene was used as an internal standard, except where peak overlap occurred; in these cases ferrocene was used as an external standard. The reference electrode was regularly checked against $\mathrm{Fc} / \mathrm{Fc}^{+}$, and was found to be stable under the explored conditions. Potentials are reported relative to that of the $\mathrm{Fc} / \mathrm{Fc}^{+}$ couple as measured under the appropriate experimental conditions.

\section{Structure determination}

A full sphere of CCD area-detector data was measured at $c a$. $153 \mathrm{~K}$ [Bruker AXS instrument; SMART/SAINT/SADABS ${ }^{13}$ (etc.) proprietary software; monochromatic Mo $\mathrm{K} \alpha$ radiation, $\lambda=0.7107_{3} \AA ; 2 \theta_{\max }=58^{\circ}$ ] yielding 70920 reflections, merging after 'empirical' (multiscan) absorption correction to 18533 unique $\left(R_{\text {int }}=0.028\right), 13314$ of these with $F>4 \sigma(F)$ being considered 'observed' and used in the full matrix least squares refinement. Anisotropic thermal parameter forms were refined for the non-hydrogen atoms, $\left(x, y, z, U_{\text {iso }}\right)_{\mathrm{H}}$ also being refined. The chlorine atoms of one of the anions were modelled as disordered over two sets of sites, occupancies set at 0.5 after trial refinement and seemingly concerted with the disorder of a pair of nearby residues modelled as (half) water molecule oxygen atoms, no associated hydrogens being located; high 'thermal motion' in association with tail 2 of the ligand is presumably also a foil for unresolved disorder. Conventional residuals $R, R_{\mathrm{w}}$ on $|F|$ [weights $\left\{\sigma^{2}(F)+4 \times 10^{-4}\left(F^{2}\right)\right\}^{-1}$ ] were $0.043,0.048$ at convergence. Pertinent results are given below and in the Tables and Figures. Neutral atom complex scattering factors were employed, computation using the Xtal 3.6 program system. ${ }^{13}$ 
Table 1 The iron atom environment in $\mathbf{2 b} . r$ is the iron-oxygen atom distance $(\AA)$; other entries in the matrix are the angles $\left({ }^{\circ}\right)$ subtended at the metal by the relevant atoms at the head of the row and column ${ }^{a}$

\begin{tabular}{|c|c|c|c|c|c|c|c|}
\hline Atom & $r$ & $\mathrm{O}(102)$ & $\mathrm{O}(21)$ & $\mathrm{O}(202)$ & $\mathrm{O}(31)$ & $\mathrm{O}(302)$ & $\mathrm{O}(41)$ \\
\hline $\mathrm{O}(11)$ & $2.300(4)$ & $71.06(6)$ & $74.79(5)$ & $92.40(7)$ & $138.91(6)$ & $150.57(6)$ & $84.09(6)$ \\
\hline $\mathrm{O}(102)$ & $2.064(2)$ & & $133.49(6)$ & $82.82(7)$ & $149.21(6)$ & $79.51(7)$ & $98.03(7)$ \\
\hline $\mathrm{O}(21)$ & $2.495(2)$ & & & $67.93(7)$ & $73.60(5)$ & $129.34(6)$ & $108.93(7)$ \\
\hline $\mathrm{O}(31)$ & $2.365(2)$ & & & & & $70.24(6)$ & $82.02(6)$ \\
\hline $\mathrm{O}(302)$ & $2.045(2)$ & & & & & & $99.93(7)$ \\
\hline $\mathrm{O}(41)$ & $1.792(2)$ & & & & & & \\
\hline
\end{tabular}

${ }^{a} \mathrm{Fe}-\mathrm{O}(n 1)-\mathrm{C}(n 01, n 1)(n=1,4)$ are: 114.7(1), 125.4(1); 113.0(1), 138.6(1); 114.9(1), 125.5(1); -, 164.2(2); $\mathrm{Fe}-\mathrm{O}(n 02)-\mathrm{C}(n 02)(n=1-3)$ are: $122.8(2)$, $132.4(2), 127.4(2)^{\circ} . \mathrm{O}(n 1) \cdots \mathrm{O}(n+11)(n=1,4)$ are: $2.917(2), 2.913(2), 2.762(2), 2.766(2) \AA$. For the $\mathrm{O}(n 1)_{4} \mathrm{plane}$, deviations $\delta \mathrm{O}(n 1)$ are $0.211(2)$, $-0.201(2), 0.231(2),-0.245(2), \delta \mathrm{Fe}$ being $0.975(1) \AA$, dihedral angles of $\mathrm{C}_{6}(n)$ to it being $72.05(6), 67.71(7), 68.44(6), 28.47(7)^{\circ}, n=1 / 2,2 / 3,3 / 4,4 / 1$; 1/3, $2 / 4$ being: $80.01(8), 81.28(8), 69.89(8), 77.62(8) ; 39.76(8), 83.87(8)^{\circ}$. $\delta \mathrm{Fe}$ from the pendant $\mathrm{O}_{2} \mathrm{C}_{2} \mathrm{~N}$ planes are: $0.622(4), 0.169(5), 0.168(4) \AA$; dihedral angles between the pendant planes and their parent $\mathrm{C}_{6}$ plane are $84.74(9), 87.4(1), 85.1(1)^{\circ}$.

Crystal/refinement data for $\mathbf{2 b}$. $[\mathrm{Fe}(\mathrm{II}-\mathrm{H})]\left(\mathrm{FeCl}_{4}\right)_{2} \cdot \mathrm{H}_{2} \mathrm{O} \equiv$ $\mathrm{C}_{62} \mathrm{H}_{90} \mathrm{Cl}_{8} \mathrm{Fe}_{3} \mathrm{~N}_{3} \mathrm{O}_{8}, M=1456.6$. Monoclinic, space group $P 2_{1} / n$ $\left(C_{2 h}^{5}\right.$, no. 14), $a=19.880(1), b=14.765(1), c=25.914(2) \AA, \beta=$ $100.681(1)^{\circ}, V=7475 \AA^{3} . D_{c}(Z=4)=1.29_{4} \mathrm{~g} \mathrm{~cm}^{-3} \cdot \mu_{\mathrm{Mo}}=9.1$ $\mathrm{cm}^{-1}$; specimen: $0.45 \times 0.45 \times 0.45 \mathrm{~mm}(\mathrm{rhomb})$; ' $T{ }^{\prime}{ }_{\min , \max }=$ $0.67,0.83 .\left|\Delta \rho_{\max }\right|=0.60(4)$ e $\AA^{-3}$

CCDC reference number 165283 .

See http://www.rsc.org/suppdata/dt/b1/b104963c/ for crystallographic data in CIF or other electronic format.

\section{Results and discussion}

\section{Ligand syntheses}

The required calix[4]arene ligands I, and III, were synthesised according to literature methods. ${ }^{9,10}$ The trisamide ligand II has been synthesised previously by adding the amide groups to a monoalkylated calix[4]arene derivative, followed by removal of the original substituent to give the trisamide. ${ }^{5}$ In this work, II was synthesised by adapting the published procedure for trialkylation of calix[4]arenes, ${ }^{11}$ giving the required trisamide in modest yield. The synthesis of calix[6]arene derivative IV was serendipitous; under conditions expected to give the hexasubstituted calix[6]arene, a tetra-substituted product (by FAB MS) was obtained in significant and reproducible yield. The cause of this has not been clarified, but the synthesis provides a convenient route to this tetra-substituted product. The ${ }^{1} \mathrm{H}$ NMR of the product is extremely complicated, and is consistent with the molecule assuming a number of different rigid conformations in solution. Variable temperature NMR studies did not simplify the spectrum in the solvent used, and thus it was not possible to determine the substitution pattern of the calix[6]arene, although previous work with different alkylating agents indicated that a 1,2,4,5-substitution pattern was likely.,14 Methylation of the remaining phenol groups of IV gave $\mathbf{V}$ which was readily characterised by ${ }^{1} \mathrm{H}$ and ${ }^{13} \mathrm{C}$ NMR. The number of signals and integration of peaks in the ${ }^{1} \mathrm{H}$ NMR was found to be consistent with 1,2,4,5-substitution. From these studies, it was concluded that IV also has the $1,2,4,5$ substitution pattern. The complex NMR spectra obtained for IV are presumably due to slow conformational change on the NMR timescale, caused by hydrogen bonds involving the unsubstituted phenol groups, although it is notable that the related bridged calix[6]arene tetraamide, where the remaining phenol groups are linked by a polyether bridge, is also conformationally restricted. ${ }^{15}$

\section{Metal complexation}

Iron complexation by the partly substituted calixarenes is clearly indicated by the rapid formation of an intensely coloured solution (purple for I, green for II and IV) when an iron salt is added to a dichloromethane-ethanol solution of the calixarene. As reported previously, III also forms an intense green solution initially, fading to a pale green solution over
$24 \mathrm{~h}$, from which the colourless iron(II) complex crystallises. ${ }^{7}$ Careful addition of an iron(III) perchlorate solution to dichloromethane-ethanol solutions of the calixarenes I, II and IV shows an increase in a broad absorbance in the visible region (I, $580 \mathrm{~nm}$; II, IV, $800 \mathrm{~nm}$ ), characteristic of a phenolateiron(III) charge transfer band, ${ }^{16}$ up to a $1: 1$ metal : ligand ratio, after which no further changes are observed. This is consistent with the formation of a $1: 1$ complex in solution for all the calixarenes studied. The complexes are readily isolated by allowing the solutions to evaporate slowly, and microanalytical and FAB MS data were consistent with the formulation of the products as $[\mathrm{Fe}(\mathbf{I}-2 \mathrm{H})]\left(\mathrm{ClO}_{4}\right)_{2}(\mathbf{1}),[\mathrm{Fe}(\mathbf{I I}-\mathrm{H})]\left(\mathrm{ClO}_{4}\right)_{2}(\mathbf{2 a})$ and $[\mathrm{Fe}(\mathrm{IV}-\mathrm{H})]\left(\mathrm{ClO}_{4}\right)_{2}(\mathbf{4})$. Attempts to study the complexation process in more polar solvents such as dmf and dmso were unsuccessful, and it appears that iron complexation does not occur under these conditions. Addition of a base is often required to induce metal complexation with ionisable calixarenes. ${ }^{1,17}$ In the present case, addition of triethylamine to the various reaction mixtures resulted in rapid precipitation of an amorphous red-brown solid which did not contain a significant proportion of the calixarene (presumably the solid is 'iron hydroxide' as no attempt was made to perform the reactions under strictly anhydrous conditions).

Reaction of trisamide II with iron(III) chloride rather than the perchlorate, resulted in the isolation of complex $\mathbf{2} \mathbf{b}$. This complex formed crystals appropriate for a single crystal X-ray study, the results of which are consistent with the formulation $[\mathrm{Fe}(\mathrm{II}-\mathrm{H})]\left(\mathrm{FeCl}_{4}\right)_{2} \cdot \mathrm{H}_{2} \mathrm{O}$, one formula unit, devoid of crystallographic symmetry, comprising the asymmetric unit of the structure. Microanalytical data indicate that the solvent water molecule is lost upon drying of the product. The structure of the complex cation is shown in Fig. 1, and pertinent bond distances and angles are listed in Table 1. The calix[4]arene assumes a distorted cone conformation, although, given the dihedral angle between phenyl ring 4 and the phenol $\mathrm{O}_{4}$ plane [28.47(7) ${ }^{\circ}$; see Table 1], it may be more appropriate to describe the conformation qualitatively as "up, up, up, out". ${ }^{1}$ The cavity defined by the phenyl rings is unoccupied.

The $\mathrm{Fe}$ atom lies in the coordination environment offered by the seven $\mathrm{O}$ atoms of the calixarene in an unsymmetrical manner, quasi-pentagonal bipyramidal, $\mathrm{O}(41,202)$ quasi-axial (Fig. 1). The shortest $\mathrm{Fe}-\mathrm{O}$ distance involves the unsubstituted phenol atom $[\mathrm{Fe}-\mathrm{O}(41), 1.792(2) \AA]$, and the longest is found for the opposite phenol ether $\mathrm{O}$ atom $[\mathrm{Fe}-\mathrm{O}(21), 2.495(2) \AA]$. $\mathrm{The} \mathrm{Fe}-\mathrm{O}$ distances increase in the order phenol, amide, phenol ether $\mathrm{O}$ atoms; this was also observed in the Fe(III) complex of diamide $\mathbf{I},{ }^{8}$ and with the exception of $\mathrm{Fe}-\mathrm{O}(21)$, the magnitudes of the comparable $\mathrm{Fe}-\mathrm{O}$ distances in the two structures differ by less than $0.07 \AA$.

\section{Electrochemical studies}

The metal complexes $\mathbf{1}, \mathbf{2 a}, \mathbf{3}$ and $\mathbf{4}$ dissolve readily in acetonitrile and dichloromethane, and the electrochemical 

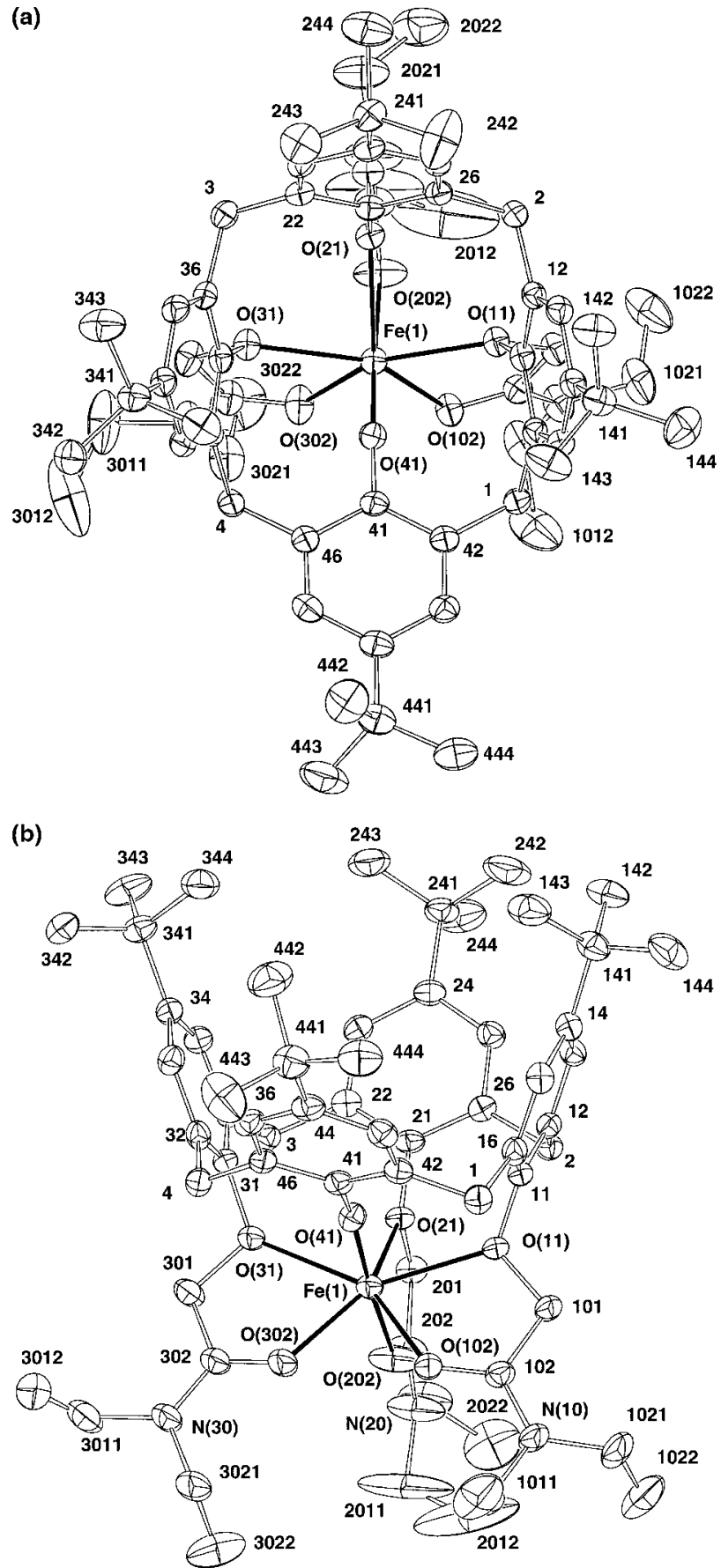

Fig. 1 Projections of the cation of $\mathbf{2 b}$ (a) down and (b) quasi-normal to the cone axis. $50 \%$ Displacement ellipsoids are shown for the non-hydrogen atoms.

behaviour of the complexes was studied in both solvents. Cyclic voltammograms for $\mathbf{3}$ and $\mathbf{4}$ were poorly defined and gave inconsistent results. The voltammograms of $\mathbf{1}$ and $\mathbf{2 a}$ were more readily studied, and the results reported here will focus on these systems.

Representative cyclic voltammograms of $\mathbf{1}$ and $\mathbf{2 a}$ in acetonitrile are shown in Fig. 2. The complex 2a undergoes a reduction at $E_{1 / 2}-0.15 \mathrm{~V}\left(v s . \mathrm{Fc}^{+} / \mathrm{Fc}\right)$; varying the scan rate showed that the process is diffusion controlled, with changes in the oxidation and reduction potentials of less than $15 \mathrm{mV}$. The separation between the oxidation and reduction potentials at a scan rate of $200 \mathrm{mV} \mathrm{s}^{-1}$ is $90 \mathrm{mV}$, compared with $75 \mathrm{mV}$ for ferrocene under the same conditions. A reduction process is also observed for $\mathbf{1}$ in acetonitrile (Fig. 2); in this case the $E_{1 / 2}$ is $-0.73 \mathrm{~V}$, and the process is somewhat less reversible, with a peak separation of $105 \mathrm{mV}$ at a scan rate of $200 \mathrm{mV} \mathrm{s}^{-1}$, increasing to $195 \mathrm{mV}$ at $1000 \mathrm{mV} \mathrm{s}^{-1}$. The behaviour in dichloro-

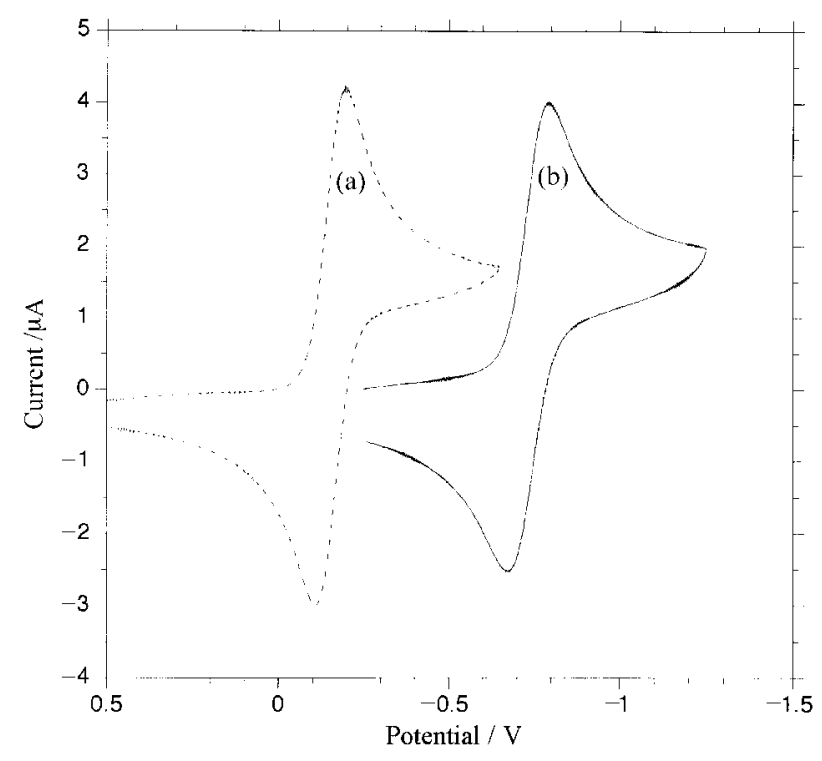

Fig. 2 Cyclic voltammograms of (a) 2a, and (b) 1 in $\mathrm{CH}_{3} \mathrm{CN}(0.10 \mathrm{~mol}$ $\mathrm{dm}^{-3} \mathrm{Bu}_{4} \mathrm{NBF}_{4}$ ), reported $v s . \mathrm{Fc}^{+} / \mathrm{Fc}$. Scan rate $200 \mathrm{mV} \mathrm{s}^{-1}$.

methane solvent is comparable to that observed in acetonitrile, albeit with poorer reversibility; for $\mathbf{1}$, the $E_{1 / 2}$ is $-0.77 \mathrm{~V}$, and for 2a, $-0.25 \mathrm{~V}\left(v s . \mathrm{Fc}^{+} / \mathrm{Fc}\right)$.

To examine this process further, controlled potential bulk electrolysis of the solutions was performed. During this procedure the solutions became colourless, and UV/vis spectroscopy confirmed that the peak at $580 \mathrm{~nm}$ for $\mathbf{1}$, and 800 $\mathrm{nm}$ for 2a were no longer present. This observation is consistent with the reduction of iron(III) to iron(II). ${ }^{18}$ When performed in acetonitrile or dichloromethane solvents the reduction was irreversible, indicating that the complex may have dissociated or precipitated. It was found that the complexes could be dissolved in dmf, and the resulting solutions were sufficiently stable (as judged by the UV/vis spectra) for bulk electrolysis experiments (although the solutions were colourless after $24 \mathrm{~h}$ indicating gradual dissociation of the complexes). In this solvent the bulk reduction process was reversible, and given that the complexes could not be synthesised in this solvent, it seems likely that the iron(III) complex is reduced without significant dissociation of the resulting iron(II) complex. These measurements show that the trisamide iron(III) complex $\mathbf{2 a}$, is more readily reduced than the bisamide complex $\mathbf{1}$, consistent with increased stability of the higher metal oxidation state with increased number of phenolate $\mathrm{O}$ donor atoms. ${ }^{16}$

Cyclic voltammetry also shows that the two complexes undergo oxidation processes, although this aspect of the electrochemistry was not studied in detail. A thorough study of the anodic oxidation of $\mathbf{I}$ in dichloromethane solvent has recently been reported, ${ }^{19}$ showing that the calixarene undergoes two irreversible oxidations (with a minor, unassigned oxidation peak also observed in cyclic voltammograms) followed by chemical reactions to give electrochemically active species (an ECE-type mechanism); preparative coulometry produced the mono- and di-calixquinones resulting from oxidation of the unsubstituted phenol groups. In the present case, the complex 2a was found to undergo an irreversible oxidation at $1.1 \mathrm{~V}$ (Fig. 3) in acetonitrile, after which a new reduction wave was observed, albeit overlapping with the process assigned to the iron(III) reduction, at approximately $-0.3 \mathrm{~V}$. This is consistent with a chemical reaction step following the initial oxidation, as observed for the uncomplexed calixarene $\mathbf{I}$.

It is interesting to note that the cyclic voltammogram for $\mathbf{1}$ in acetonitrile exhibits an oxidation that is at least quasi-reversible at $E_{1 / 2} 0.62 \mathrm{~V}$ (Fig. 4); scanning to higher potentials shows a second, irreversible, oxidation process at $1.1 \mathrm{~V}$. The most probable assignment for these oxidation processes, is ligand-centred oxidation to give phenoxyl radicals, as is observed in the free 


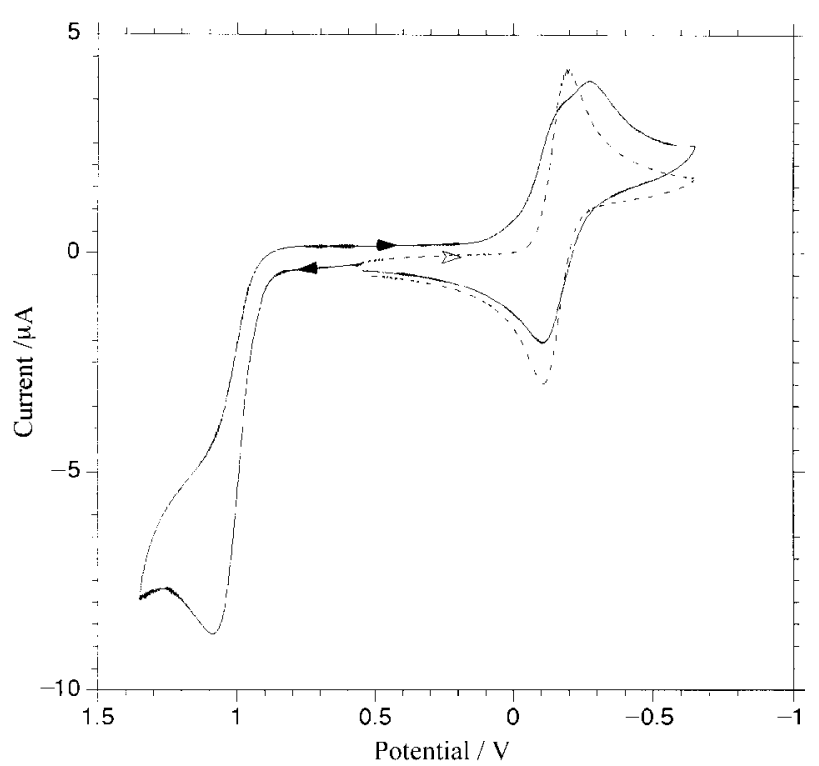

Fig. 3 Cyclic voltammograms of $\mathbf{2 a}$ in $\mathrm{CH}_{3} \mathrm{CN}\left(0.10 \mathrm{~mol} \mathrm{dm} \mathrm{dm}^{-3}\right.$ $\mathrm{Bu}_{4} \mathrm{NBF}_{4}$ ), reported $v s . \mathrm{Fc}^{+} / \mathrm{Fc}$. Scan rate $200 \mathrm{mV} \mathrm{s}^{-1}$.

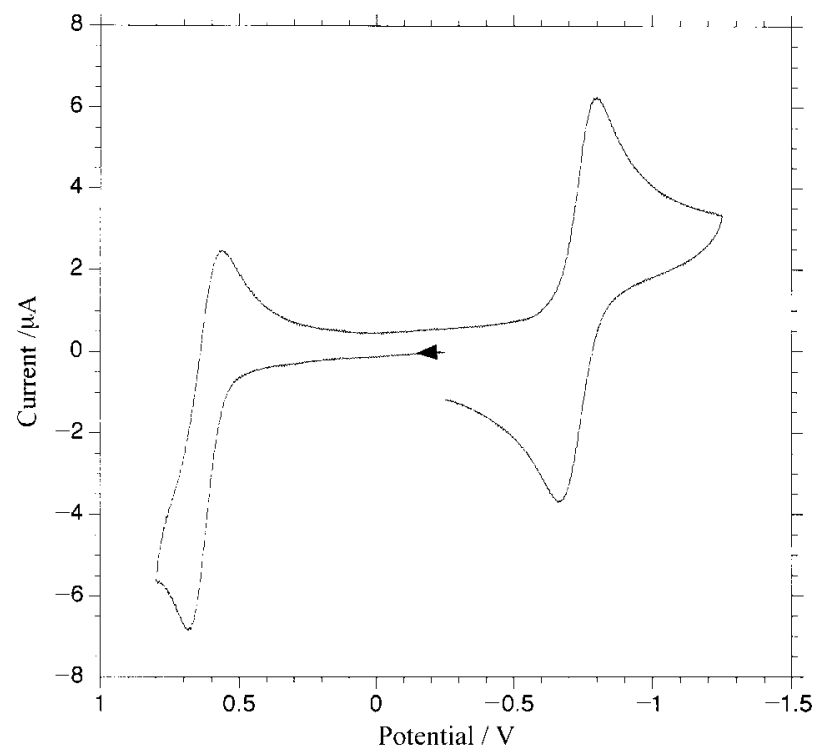

Fig. 4 Cyclic voltammogram of 1 in $\mathrm{CH}_{3} \mathrm{CN}\left(0.10 \mathrm{~mol} \mathrm{dm} \mathrm{dm}^{-3}\right.$ $\mathrm{Bu}_{4} \mathrm{NBF}_{4}$ ), reported $v s . \mathrm{Fc}^{+} / \mathrm{Fc}$. Scan rate $500 \mathrm{mV} \mathrm{s}^{-1}$.

ligand $\mathbf{I} .{ }^{19}$ Presumably coordination to the metal ion stabilises the radical species sufficiently for the process to be quasireversible in some cases (Fig. 4), whereas in the free calixarene, this is not observed. Electrochemical generation of a range of coordinated phenoxyl radicals has been reported; for example, Wieghardt et al. have described detailed characterisation of such species generated from phenol-functionalised triazacyclononane derivatives. ${ }^{16}$ It should be noted, however, that electrochemical oxidation of aryl ether units has also been reported in studies of a tert-butylcalix[4]arene tetraester, ${ }^{20}$ and thus definitive assignment of the anodic processes observed requires further work.

\section{Conclusions}

Iron(III) complexes of the calix[4]arene trisamide II, and the calix[6]arene tetraamide IV, have been synthesised, both forming 1:1 complexes under the conditions explored; the former was structurally characterised as the $\mathrm{FeCl}_{4}^{-}$salt. The electrochemical behaviour of the trisamide calix[4]arene iron complex 2a, and the previously described bisamide calix[4]arene iron complex 1, was studied. Reduction of the complexes gave the related iron(II) species, with complex 2a being more readily reduced than 1. Oxidation of the complexes was also observed, this process being assigned to oxidation of the phenoxy moieties.

\section{Acknowledgements}

This work was supported in part by the ARC Small Grant Scheme, and an Australian Postdoctoral Research Fellowship. M. I. O. is grateful to Assoc. Prof. Jack Harrowfield for providing laboratory facilities.

\section{References}

1 C. D. Gutsche, in Calixarenes Revisited, ed. J. F. Stoddart, The Royal Society of Chemistry, Cambridge, 1998.

2 F. Arnaud-Neu, M. A. McKervey and M.-J. Schwing-Weill, in Calixarenes 2001, ed. Z. Asfari, V. Böhmer, J. Harrowfield and J. Vicens, Kluwer Academic Publishers, Dordrecht, Boston, London, 2001, p. 385

3 M. A. McKervey, M. J. Schwing-Weill and F. Arnaud-Neu, in Comprehensive Supramolecular Chemistry, ed. J. L. Atwood, J. E. D. Davies, D. D. McNicol and F. Vögtle, Pergamon, New York, 1996, p. 537; A. Casnati, L. Baldini, N. Pelizzi, K. Rissanen, F. Ugozzoli and R. Ungaro, J. Chem. Soc., Dalton Trans., 2000, 3411; F. ArnaudNeu, S. Barboso, A. Casnati, A. Pinalli, M. J. Schwing-Weill and R. Ungaro, New J. Chem., 2000, 24, 967; M. F. Arnaud-Neu, S. Barboso, F. Berny, A. Casnati, N. Muzet, A. Pinalli, R. Ungaro, M. J. Schwing-Weill and G. Wipff, J. Chem. Soc., Perkin Trans. 2, 1999, 1727; N. Muzet, G. Wipff, A. Casnati, L. Domiano, R. Ungaro and F. Ugozzoli, J. Chem. Soc., Perkin Trans. 2, 1996, 1065.

4 P. D. Beer, M. G. B. Drew, A. Grieve and M. I. Ogden, J. Chem. Soc., Dalton Trans., 1995, 3455; P. D. Beer, M. G. B. Drew, M. Kan, P. B. Leeson, M. I. Ogden and G. Williams, Inorg. Chem., 1996, 35, 2202; P. D. Beer, M. G. B. Drew and M. I. Ogden, J. Chem. Soc., Dalton Trans., 1997, 1489.

5 M. P. Oude Wolbers, F. C. J. M. Van Veggel, R. H. M. Heeringa, J. W. Hofstraat, F. A. J. Geurts, G. J. Van Hummel, S. Harkema and D. N. Reinhoudt, Liebigs Ann. Chem., 1997, 2587.

6 F. Arnaud-Neu, G. Barrett, D. Corry, S. Cremin, G. Ferguson, J. F. Gallagher, S. J. Harris, M. A. McKervey and M. J. Schwing-Weill, J. Chem. Soc., Perkin Trans. 2, 1997, 575; C. Wieser, D. Matt, J. Fischer and A. Harriman, J. Chem. Soc., Dalton Trans., 1997, 2391.

7 P. D. Beer, M. G. B. Drew, P. B. Leeson and M. I. Ogden, J. Chem. Soc., Dalton Trans., 1995, 1273.

8 P. D. Beer, M. G. B. Drew, P. B. Leeson and M. I. Ogden, Inorg. Chim. Acta, 1996, 246, 133.

9 E. M. Collins, M. A. McKervey, E. Madigan, M. B. Moran, M. Owens, G. Ferguson and S. J. Harris, J. Chem. Soc., Perkin Trans. 1, 1991, 3137.

10 A. Arduini, E. Ghidini, A. Pochini, R. Ungaro, G. D. Andreetti, G. Calestani and F. Ugozzoli, J. Inclusion Phenom., 1988, 6, 119.

11 C. D. Gutsche, B. Dhawan, J. A. Levine, K. H. No and L. J. Bauer, Tetrahedron, 1983, 39, 409.

12 (a) P. D. Beer, Z. Chen and M. I. Ogden, J. Chem. Soc., Faraday Trans., 1995, 91, 295; (b) EChem software, ADInstruments, Sydney, Australia, 1995, version 1.3.1.

13 SMART/SAINT, Software for the CCD Detector System, Bruker Analytical X-Ray Systems, Inc., Madison, WI, 1998; G. M. Sheldrick, SADABS, Program for Siemens area detector absorption correction, Institut für Anorganische Chemie, Universität Göttingen, 1996; ed. S. R. Hall, D. J. du Boulay and R. OlthofHazekamp, The Xtal 3.6 System, University of Western, Australia, 2000.

14 J. M. Harrowfield, M. Mocerino, B. W. Skelton and A. H. White, Aust. J. Chem., 1998, 51, 123.

15 A. Casnati, P. Jacopozzi, A. Pochini, F. Ugozzoli, R. Cacciapaglia, L. Mandolini and R. Ungaro, Tetrahedron, 1995, 51, 591.

16 B. Adam, E. Bill, E. Bothe, B. Goerdt, G. Haselhorst, K. Hildenbrand, A. Sokolowski, S. Steenken, T. Weyhermuller and K. Wieghardt, Chem. Eur. J., 1997, 3, 308.

17 P. Thuéry, M. Nierlich, J. Harrowfield and M. Ogden, in Calixarenes 2001, ed. Z. Asfari, V. Böhmer, J. Harrowfield and J. Vicens, Kluwer Academic Publishers, Dordrecht, Boston, London, 2001, p. 561.

18 D.-H. Jo, Y.-M. Chiou and L. Que, Jr., Inorg. Chem., 2001, 40, 3181.

19 R. Vataj, A. Louati, C. Jeunesse and D. Matt, Electrochem. Commun., 2000, 2, 769

20 A. Pailleret and D. W. M. Arrigan, Electrochem. Commun., 2001, 3, 24

J. Chem. Soc., Dalton Trans., 2001, 3073-3077 